\title{
Fundamental ASPECTS OF OIL and Gas LaW Revisited
}

\author{
DON GREEnfield" and Jay TODESCo“
}

The authors review certain fundamental principles of Canadian oil and gas law. concentrating on three main areas: basic principles of ownership and operation in the oil and gas industry: aspects of oil and gas agreements: and international petroleum agreements. In discussing each of these subjects. the authors consider issues of significance to practitioners of oil and gas law:
Les auteurs examinent certains principes fondamentaux de la loi canadienne sur le pétrole el le gas naturel, en se concentrant sur trois grands domaines, à savoir les principes de base de la proprieté et de l'exploitation dans le secteur peitrolier ef gazier, les aspects des ententes concernant le pítrole et le gaz naturel ef les ententes pétrolières internationales. Pour chacun de ces sujets, les auteurs prennent en consideration les questions qui sont importantes pour les praticiens dans le domaine du pétrole ef du gaz naturel.

\section{TABLE OF CONTENTS}

I. INTRODUCTION ................................ 75

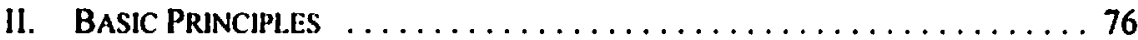

A. SPL.tT OWNERShIP OF PETROLEUM AND NatURAI. GAS $\ldots \ldots \ldots 76$

B. The Freehold Petrolleum and Natural Gas Lease $\ldots \ldots \ldots \ldots 78$

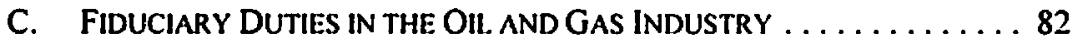

III. ASPECTS OF OIL, AND GAS AGREEMENTS $\ldots \ldots \ldots \ldots \ldots \ldots \ldots \ldots$ 9I

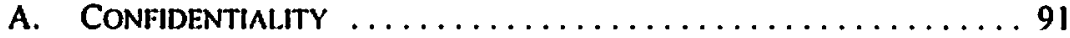

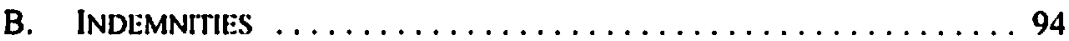

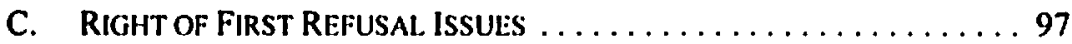

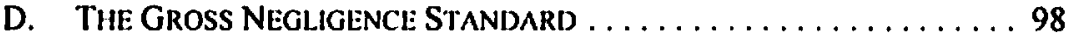

IV. International. Petrol.fum Agreements . . . . . . . . . . . 99

A. THE EVOLUTION OF CONTRACT STRUCTURI: IN THE.

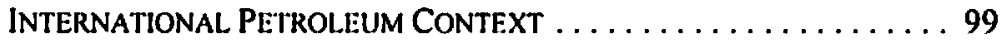

B. THE 2002 AIPN MODEI. OPERATING PROCEDURE:

A SUMMARY OF SIGNIFICANT CHANGES $\ldots \ldots \ldots \ldots \ldots \ldots 105$

APPENDIX A - HABENDUM Cl.AUSE $\ldots \ldots \ldots \ldots \ldots \ldots \ldots \ldots \ldots 111$

\section{INTRODUCTION}

A basic analytical tool of lawyers and courts alike is to revert to first principles in order to develop legislation or forms of agreement that address emerging legal phenomena. In the context of oil and gas law, basic principles represent the legal framework for the ownership and operation of the resource. When technological or commercial innovation occasions a shift in industry practice, it is to these principles that practitioners turn to articulate legal responses to such developments. For this reason and others, these fundamentals merit reexamination on a regular basis. This article reviews certain of these fundamental principles.

- Parner, Benncit Joncs L.L.P. Calgary, Alberta.

* Associate General Counsel. EnCana Corp. The authors would like to thank J.P. Pham, Vivek Warrier. Andrew Lamb, David Dorrans and Ryan Robertson of Bennett Jones LL.P for their assistanee in preparing this article. 
Due to the expansive nature of this topic and the potential for overlap with other presentations to be delivered at this conference, we have narrowed the scope of the article to three main subject areas: basic principles of ownership and operation in the oil and gas industry; aspects of oil and gas agreements; and aspects of international petroleum agreements. Within each of these sections, we have attempted to identify and revisit core legal issues of enduring relevance to the oil and gas lawyer.

\section{BASIC PRINCIPLES}

\section{A. Split OWNership of Petroleum and Natural GaS}

Given the comparatively short history of the Canadian oil patch, the concept of split title to petroleum and natural gas is of venerable origin. Recognition of split ownership of petroleum and natural gas is derived from the wording of early Canadian Pacific Railway Co. (CPR) land grants. Such bequests reserved to the CPR all "coal, petroleum, and valuable stone" which could be found to exist in, upon or under the lands granted to the settler. This proviso was ultimately interpreted in the seminal case of Borys $v$. Canadian Pacific Railway ${ }^{1}$ to exclude natural gas from the substances reserved to the CPR. The recognition of the possibility of distinct ownership of petroleum and natural gas gave rise to further questions, given that the numerous hydrocarbon substances which are habitually found in oil and gas reservoirs do not always neatly fall into one category or the other. Examples of such substances include "solution gas," defined by the Alberta Court of Appeal to mean gas that was dissolved in liquid hydrocarbons in the reservoir prior to human disturbance, but that emerges from solution as gas at the surface following changes in temperature or pressure. Similarly, "evolved gas" has been judicially defined as solution gas that emerges from liquid hydrocarbons in the reservoir due to changes in temperature or pressure. ${ }^{3}$

As mentioned above, the framework for split ownership was established by the Privy Council decision in Borys. In 1906, the Borys family entered into an agreement to purchase a quarter section of homestead lands from the CPR in what was to become the Leduc Woodbend Field. The lands in question were eventually passed down to Michael Borys. The grant in question contained the same formulaic hydrocarbon reservation described above, providing that the CPR was entitled to all "coal, petroleum, and valuable stone which may be found to exist within, upon or under" the lands. In 1949, Imperial Oil Limited (Imperial) entered into a petroleum lease agreement with the CPR and applied for a licence to drill on the lands.

The Privy Council began its decision by stating, as a general principle of law, that because petroleum, gas and water are fugacious substances, "those who make the recovery become owners of the material which they withdraw from any well which is situated on their property or from which they have authority to draw."4 In this statement the Privy Council inextricably linked ownership to recovery of the substances, reaffirming the applicability of the rule of

[1953] 2 D.L.R. 65 (P.C.) [Bons].

Anderson v. Amoco Canada Oil and Gas (1998), 5 Alta. L.R. (4th) 54 at 63 (C.A.) [Anderson].

Jbid. at 63.

Ibid. al 68. 
capture articulated in the United States Supreme Court judgment of White C.J. in Ohio Oil v. Indiana, a leading authority for the qualified ownership theory of oil and gas law. Under this theory, oil and gas cannot be owned until they are captured or recovered.

The Privy Council held that the word petroleum, as conceived in the vernacular at the time of the grant, denoted all substances which existed as liquid "in the mine." $T$ The right to produce solution gas was thus found to be held by the petroleum owner. The determination of ownership is to be made by interpretation of the language of the reservation at the time of the grant under initial reservoir conditions.

The Privy Council further ruled that the CPR and Imperial had the right to extract their petroleum notwithstanding the inevitable escape of Mr. Borys' gas cap gas, provided that their operations were conducted in compliance with the applicable conservation regulations. The reservation in question implicitly vested the mineral owner with the right to work those minerals.

The controversy relating to ownership of substances such as solution gas and evolved gas persisted subsequent to the Privy Council's pronouncements in Borys. These matters were before the Court of Queen's Bench of Alberta in numerous actions where the preliminary legal issue of ownership of gas was to be determined in a single consolidated trial. The decision of the Court in this matter was reported as Anderson v. Amoco Canada Oil and Gas Lid.' According to the trial judge, Borys stood for three "clear and uncontroversial" propositions: "(1) solution gas belongs to the petroleum owner; (2) free gas or primary gas cap gas belongs to the non-petroleum owner; and (3) gas that emerges from solution in the reservoir, at the bottom of the well bore, at the surface, or anywhere in-between, belongs to the petroleum owner."8

All three of these propositions are derived from the conclusion that ownership is to be determined under initial reservoir conditions, prior to human disturbance. As a result, the gas owner in split title lands held title to all substances that existed in a gaseous state in the pool prior to human disturbance, including gas cap gas and the condensate and natural gas liquids contained therein. The petroleum owner held title to any hydrocarbons produced from split title lands that existed in a liquid state in the pool prior to human disturbance, including any evolved gas that emerged from petroleum in the reservoir as the result of production-induced reservoir pressure decline.

A thin layer of water lines the gas or petroleum-filled pores of the reservoir rocks in most oil and gas pools. In addition, many oil and gas pools are bounded below by reservoir rocks whose pores are completely filled with water. The trial judge referred to this water as "connate water." Connate water contains solution gas. Just as production-induced reservoir pressure decline causes gas to evolve from solution in petroleum, gas evolves from solution in connate water as the result of production from a pool. 
At trial, expert estimates of how much of the total gas produced from a pool could be attributed to gas which had evolved from connate water ranged from 0.34 percent to 1.50 percent. $^{10}$

Justice Fruman (as she then was) held that gas evolved from connate water produced from wells on split title land belonged to the petroleum owners, that water being liquid under initial reservoir conditions. The plaintiffs appealed. The Court of Appeal substantially agreed with the findings of the lower Court, and definitively pronounced that Borys stood for the principle that ownership was to be determined "based upon an interpretation of the reservation at the time of the grant when the hydrocarbons were at initial reservoir conditions, before any human intervention and phase changes had occurred." "However, the Court of Appeal rejected Fruman J.'s conclusion that gas dissolved in connate water belonged to the petroleum owner. Though the gas dissolved in connate water existed as a liquid under initial reservoir conditions, water did not form part of the subject matter of the reservation, nor would it fall within the vernacular meaning of the term "petroleum." 12 Thus, gas dissolved in connate water belonged to the gas owner.

In considering this issue, J.B. Ballem concluded that "it seems at least probable that a Canadian Court, faced with the question of whether or not substances such as hydrogen sulfide, nitrogen, helium, and carbon dioxide that form part of the natural gas in a reservoir are included in a grant of petroleum, natural gas and related hydrocarbons," ${ }^{13}$ would hold that they were so included.

\section{B. The Freehold Petroleum and Natural, Gas Lease}

A fairly small proportion, perhaps 29 percent, of petroleum and natural gas rights in Alberta are freehold. The oil and gas rights to freehold lands are usually exploited through freehold petroleum and natural gas leases granted by the fee simple mineral owner to an oi] company. The form of freehold lease used in Canada is derived substantially from American precedents, though certain aspects of the lease have evolved to reflect factors peculiar to Canadian jurisprudence.

Most freehold oil and gas leases are "unless" type leases. Three of the more significant clauses forming part of such "unless" type freehold oil and gas leases are the habendum, shut-in and offset well clauses. ${ }^{14}$

The habendum clause sets forth both the primary term of the lease and the conditions under which the primary term may be extended. ${ }^{15}$ The primary term of the lease is a fixed period. The lessee may hold the lease for the entire length of the primary term, whether or not it has drilled a well on the land. However, the first proviso indicates that where the lessee has not commenced operations for the drilling of a well, the lease will terminate on the

The Oil and Gas lease in Canada, 3rd ed. (Toronto: University of Toronto Press, 1999) at 116. 
anniversary date unless a delay rental is paid. Payment of this rental defers the need to commence drilling until the next anniversary. The second proviso also deals with nonproduction during the primary term. The so-called "dry hole" clause treats the drilling of a dry well, or the abandonment of a well, as if no drilling has taken place. The lessee must either commence drilling another well or pay the delay rental, otherwise the lease will terminate on the next anniversary date. Ballem notes that the tendency to grant shorter primary terms has led to the elimination of both delay rentals and the dry hole clause in the Canadian Association of Petroleum Landmen (CAPL) 99 Lease. $^{16}$

The habendum clause allows for the extension of the term beyond the primary term. Ballem states that "one may safely say that it is 'unquestionable' that production from the lands will extend the lease beyond the primary term." the end of the primary term if the leased substances are not being produced then or, if the lease has continued beyond the primary term through production, then the lease will terminate when those substances are no longer produced.

Ballem notes that a "literal interpretation of the phrase 'and so long thereafter as the leased substances are produced' would appear to require continuous and uninterrupted production." 18 The third proviso attempts to prevent the termination of the lease where production has ceased and the lessee has taken steps to place the lands back on production. In the past, courts have interpreted the proviso very strictly. ${ }^{19}$ However, recently the courts have attached more importance to the intention of the lessee to place the lands on production and have abandoned their hard line approach. ${ }^{20}$ The third proviso allows for the extension of the lease where drilling or working operations have begun either during the primary term or during any extension thereof. In addition, the proviso allows for the cessation of drilling or working operations for up to 90 consecutive days. This language avoids the argument, rejected in $\mathrm{Cull}$, that production must begin at the very moment drilling is finished or the lease will automatically expire. Where the drilling or working operations result in the production of leased substances, the lease will continue so long thereafter as the leased substances are produced.

In addition, the third proviso provides for further extensions where drilling or working operations are interrupted or suspended as the result of any cause whatsoever beyond the lessee's reasonable control, or where the well is not producing in accordance with good oil field practice. Other similar clauses provide for extensions where production ceases "as the result of, a lack of or intermittent market or any cause whatsoever beyond the lessee's reasonable control."21

There are two significant issues raised by the third proviso. The first involves the definition of production and the second involves the definition of drilling or working

Supra note 13 at $129,135$.

Ibid. at 131 .

Ibid. al 134.

Canada Cities Petroleum v. Kininmonth. [1964] S.C.R. 439 [K'ininmonth].

Canadian Superior Oil Ltd. v. Cull, [1972] S.C.R. 89 [Cull].

See discussion of "lack of or intermittent market" and "any cause whatsoever beyond the lessee's control" in the context of the shut-in well clause, infra note 29 and accompanying text. 
operations. With respect to the first issue, while it is clear that production will extend the term of the lease beyond the primary term, it is not clear what constitutes production. Ballem is of the view that "[i]f an operator is prepared to physically produce a well, regardless of profit or loss, it is submitted that a Canadian court would hold that the "are produced" test had been met."22 Leases, however, may contain specific reference to production in paying quantities in the habendum clause. In North Western Utilities Lid. v. Peyto Oils Lid., Lomas J. cited Oil and Gas Law, ${ }^{23}$ for the proposition that "[f]or purposes of the habendum clause, that is, for the purpose of keeping the lease in force after the expiration of the primary term, paying quantities means production in quantities sufficient to yield a return in excess of operating costs even though drilling and equipment costs may never be repaid."24

The second issue is what constitutes drilling or working operations. While the terms of the proviso make continuous production unnecessary, where there is no production, the lessee must commence drilling or working operations within a reasonable time period. In Cull, Martland J. accepted the trial judge's finding that activities carried out with reasonable diligence and dispatch consistent with good oil field practice with a bona fide intention to proceed diligently to place the well on production serve to continue the lease. ${ }^{25}$ The clause in question in Cull required the lessee to drill a well to completion with reasonable diligence and dispatch. In Montreal Trust $v$. Williston Wildcatters, the Court concluded that the term "working operations" must be interpreted within the context and purpose of the lease. ${ }^{26} \mathrm{As}$ the lease centred on the production of oil, something more than merely casual work and planning was necessary. Justice Gerwing stated that work should "be disallowed which is a mere pretense and does not demonstrate a bona fide intent to proceed with diligence."27

While the third proviso continues the lease where drilling or working operations are interrupted or suspended and production has ceased outside of the primary term, the courts have held that it has no application to wells completed within the primary term. ${ }^{28}$

A typical shut-in clause relies on the notion of deemed production, a fiction created in order to allow the lessee to have the lease continue during times when it is unreasonable or impossible to have actual production. These provisions balance the lessor's desire to generate royalties with the lessee's desire to have the lease continue during those periods in which it would be impossible or unreasonable to maintain production. Where there is no actual production at the end of the primary term, the lease would automatically terminate unless the lessee makes a payment to the lessor, which serves to create constructive production. The well is thus deemed to be producing and the lease remains in force.

Some versions of the shut-in clause allow deemed production only where the leased substances are not produced "as a result of, a lack of, or an intermittent, market or lack of

(991).

Ballem, supra note 13 at 132.

R. Williams \& Charles J. Meyers, OIl and Gas Law, vol. 8 (New York: Matthew Bender, Northvesterm Utilities Lid. v. Peyto Oils Lid. (1984), 49 A.R. I at 27 (Q.B.) [Peyto].

Cull, supra note 20 at 32.

[2002] 10 W.W.R. 633 at para. 42 (Sask. C.A.).

Jbid. at para. 32.

White Resource Management Lid. v. Durish, (1998), 230 A.R. 201 (Q.B.). 
transportation facilities or any cause whatsoever beyond the Lessee's reasonable control."29 In 549767 Alberta Lid. v. Teg Holdings Lid., Deyell J. followed both Blair Estate Limited v. Altana Exploration ${ }^{30}$ and Canada-Cities Service Petroleum v. Kininmonth ${ }^{31}$ in asserting that "it is for the defendants to show that there was a lack of market or transportation facilities in order to 'save' the leases." 32

Although leases also allow the wells to be shut-in where production ceases because of "any cause whatsoever beyond the lessee's control," the scope of this proviso has been restricted by the courts. In Kininmonth, the Court concluded that events that were foreseeable at the time of drilling the well would not pass the threshold of this proviso. It is clear from the case law that for a well to be properly shut-in and the lease to continue, the lessee must show that the non-production of the well is for a valid reason as specified under that lease.

In all cases, under both the habendum and shut-in clauses, the leases do not oblige the lessee to take any action. The lessee has the option of doing nothing and of making no payments to the lessor; however, they run the risk of having the leases terminated.

Where there is drainage of petroleum or natural gas by producing wells drilled on laterally adjoining lands, the lease imposes an obligation on the lessee to act pursuant to an offset well clause. A typical offset well clause serves to protect the lessor against drainage. Thus, the offset well clause contemplates that the lessor does not own the lands where the offset well is located.

According to the decision in Peyto, the onus is on the party seeking to enforce the clause to show that there has been drainage. ${ }^{33}$ Where drainage has been proven, the lessee has three options. The first is to drill a well on the leased lands laterally adjoining the offset well into the same formation as the offset well. The second option is to pay a royalty equivalent to the royalty that would have been payable if the offsetting well were actually being produced from a well on the leased lands. The third is to surrender the portion of the leased lands comprised of the spacing unit laterally adjoining the spacing unit on which the offset well is producing. The Court in Mobil Oil Canada, Ltd. v. Storthoaks (Rural Municipality) noted that where there is no general right of surrender, the election to pay a royalty may negate the ability to re-elect to surrender the lease. ${ }^{34}$ Ballem notes that a "failure to comply with an offset drilling obligation, unlike the drilling commitment, does not lead to automatic termination of the lease." 35 However, if the lessee fails to remedy the default within the time required by the default clause, the lease will terminate. In addition to termination of the lease, damages may be awarded for failure to drill an offset well. The general principle is that the lessor should be put in the same position as it would have been in if the contract had been performed. However, the onus of proving damage rests on the complaining party, and a court will take into consideration evidence regarding the likelihood of the well's success.

[1997] A.J. No. 32 (QL.) at para. 19 (Q.B.)

(1987), 53 Alta. L.R. (2d) 419 (C.A.).

(1963), 44 W.W.R. 392 (Alta. S.C.(A.D.)).

Supra note 29 at para. 4.

Supra note 24 at para. 121.

[1976] 2 S.C.R. 147 at 155.

Supra note 13 at 196. 
The offset well clause typically allows the lessee to avoid the obligation to drill a well in two instances. The first instance is where the offsetting well ceases to be capable of regular commercial production before the six-month period has expired. "Commercial production" is output that, after a production test of 30 consecutive days, and considering the cost of drilling and production operations, would commercially and economically warrant the drilling of a like well in the vicinity of the offset well. Secondly, the offset well clause also relieves the lessee of the obligation to drill where a producing well capable of commercial production on the spacing unit adjacent to the offset well already exists. A final limiting feature of the offset well clause is the natural gas proviso. Where this proviso exists, there is a duty upon the lessee to attempt to arrange an adequate and commercially profitable market for the natural gas. ${ }^{36}$

The Canadian Association of Petroleum Landmen (CAPL) leases have made some significant changes to the offset well clauses. Under these leases, the obligation to drill does not arise where the lessor owns even a portion of the lands in which the offset well is located. The CAPL leases also make it clear that only a well drilled subsequent to the date of the lease can create an offset. The CAPL 99 Lease, ${ }^{37}$ for the first time, includes a reference to a spacing unit diagonally adjoining the leased lands, as well as laterally adjoining the lands.

\section{Fiduciary Duties in the OIL AND Gas INDUSTRY}

Since the mid-1980s, Alberta courts have taken some notable steps to extend the application of fiduciary precepts to typical oil and gas industry situations. Despite these wellknown incursions, in most circumstances involving sophisticated commercial parties, the courts have proven loath to recognize the existence of fiduciary obligations. Historically, fiduciary theory emerged as a corollary to the concept of the equitable trust. The trustee's relationship with the beneficiary was one of uberrimae fides or "utmost good faith," incorporating stringent obligations of loyalty and fidelity ${ }^{38}$ The duty arising in the context of the trust relationship required that the fiduciary strictly adhere to the best interests of the beneficiary in all matters related to the subject matter of the trust. In the commercial context, it is not generally self-evident what relationships will invite the application of fiduciary principles and obligations.

The decision of the Supreme Court of Canada in Lac Minerals Lid. $v$. International Corona Resources LId. ${ }^{39}$ is representative of the Courts' disinclination to impose fiduciary duties in a commercial setting. International Corona Resources Ltd. (Corona) and Lac Minerals Ltd. (Lac) were negotiating towards a joint venture agreement. Throughout the course of the negotiations, Lac received valuable information from Corona on the viability of the area for gold production. Lac then made an undisclosed bid for the adjacent property and was able to outbid Corona. This property was developed by Lac on its own account and proved to be productive.

\footnotetext{
1." Albrecht v. Imperial Oil Led. (1957), 21 W.W.R. 560 (Alta. S.C.(T.D.)).

Calgary, Canadian Association of Petroleum Landmen, 1999.

M. Ellis, Fiduciary Duties in Canada (Toronto: Carswell, 2000) at I-2.

[1989] 2 S.C.R. 574 [Lac Minerals].
} 
The Court imposed liability on Lac for breach of confidence, recognized the existence of a constructive trust binding the parties and required Lac to hand over the property to Corona, subject to reimbursement for the cost of improvements and the amount paid for the purchase price. However, the majority of the Court held that no fiduciary relationship existed. Justice Sopinka restated and applied the criteria established by Wilson J. in Frame v. Smith for the existence of a fiduciary relationship:

Relationships in which a fiduciary obligation has becn imposed secm to possess three general characteristics:

$$
\begin{aligned}
& \text { The fiduciary has scope for the exercise of some discretion or power. } \\
& \text { The fiduciary can unilaterally exercise that power or discretion so as to affeet the } \\
& \text { beneficiary's legal or practical interests. } \\
& \text { The beneficiary is peculiarly vulnerable to or at the mercy of the fiduciary holding the } \\
& \text { discretion or power. }
\end{aligned}
$$

Justice Sopinka held that the third element, vulnerability or dependency, was indispensable to the existence of a fiduciary relationship: "It is rare that [fiduciary duty] is required in the context of an arm's length commercial transaction.... In my opinion, equity's blunt tool must be reserved for situations that are truly in need of the special protection that equity affords." ${ }^{.41}$

The Court held that when confronted with a relationship that is not prima facie a fiduciary relationship (such prima facie situations include agent and principal, trustee and beneficiary, director and corporation, solicitor and client or partners), one must examine the circumstances of that relationship in light of the general characteristics of fiduciary relationships. The Court noted that a fiduciary relationship may exist notwithstanding that not all of the characteristics articulated by Wilson J. are present, but that the element of vulnerability is indispensable. This element was held not to exist in the context of the relationship between Corona and Lac. The parties were experienced mining promoters and both had access to geologists, engineers and lawyers. Corona also had the opportunity to require Lac to enter into a confidentiality agreement.

This analysis has been adopted by many Canadian courts, including the Court of Queen's Bench of Alberta in Luscar Lid. v. Pembina Resources Lid. ${ }^{42}$ (discussed in detail later in this article) and the Ontario High Court (General Division), in Ontex Resources Lid. v. Metalore Resources $L$ Ld., ${ }^{43}$ a case involving the mining industry. included the finding that a fiduciary relationship did exist based on the frame lest, was overturned on appeal ((1993). 13 O.R. (3d) 229 (C.A.)). In the appeal decision, the Cour did not tefer to the test; it held that the agreement before it could not be interpreted as having created such a relationship because certain conditions precedent to the existence of the "joint venture" contemplated by the agreement had not then been satisfied. It is therefore arguable that a Court might look for the existence of a signal relationship before even applying the test. 
In Hodgkinson v. Simms, ${ }^{44}$ the Supreme Court of Canada found that a party becomes a fiduciary where it, acting pursuant to statute, agreement or unilateral undertaking, has an obligation to act for the benefit of another and that obligation carries with it a discretionary power. In that case, a financial advisor recommended an investment to his client in which the advisor had a pecuniary interest without disclosing the interest. The client followed the advice and subsequently lost a large sum of money.

It must be recognized (and the Court was eager to emphasize) that the relationship before the Court in Hodgkinson was a professional advisory relationship that could readily be distinguished from an arm's length commercial relationship such as that between working interest partners. It is rare that the parties to a commercial relationship could legitimately have expectations like those of the client in Hodgkinson. In cases involving commercial relationships in contract, the courts tend to apply the principles of contract law as opposed to fiduciary law to settle disputes.

\section{Oll AND GAS OPERATIONS}

Exploration, development and operation of joint lands are normally managed by an operator appointed pursuant to the CAPL Operating Procedure. ${ }^{45}$ These management responsibilities are carried out for the benefit of the joint account and on behalf of the joint operators.

The CAPL Operating Procedure invests an operator with significant power and discretion in the operation of the joint lands. An attempt to define this relationship is made in clause 1501, which asserts that the parties are tenants-in-common and that the relationship is not a partnership or joint venture. Despite such disavowals, courts in Alberta and elsewhere have recognized various forms of fiduciary relationships amongst oil and gas industry participants. Where a fiduciary relationship arises between arm's length commercial parties, the fiduciary's duties are generally delineated by the terms of the agreements and the course of dealing between itself and the beneficiary. In the oil and gas context, these issues have arisen in relation to allegations of self-dealing, breach of area of mutual interest (AMI) clauses, breach of production marketing provisions and the misuse of funds and other joint property.

\section{JOINT VENTURES}

Canadian jurisprudence clearly demonstrates that the parties to a joint venture stand in a fiduciary relationship to each other, similar to those owed by partners, at least in some respects. ${ }^{46}$

In the Court of Queen's Bench of Alberta decision of Matchett $v$. Blue Gold Drilling Lid. ${ }^{47}$ Matchett and Blue Gold Resources Ltd. (Blue Gold) had entered into a joint venture agreement under which Matchett was obligated to offer Blue Gold a 51 percent interest in 
the oil and gas plays he developed. Instead, Matchett and another participant retained certain promising prospects, thereby usurping opportunities that, by virtue of the agreement between the parties, belonged to the joint venture.

The Court agreed with the complainant's assertion that Matchett had breached fiduciary duties owed to Blue Gold arising from the Joint Venture Agreement. The circumstances of the arrangement and Matchett's subsequent actions were held to constitute a fiduciary relationship resulting in duties that were subsequently breached.

The mere fact that parties are joint venture partners does not mean that any claim can be successfully made under the umbrella of fiduciary obligation. If there is no traditional fiduciary obligation, it will be difficult for a plaintiff to make this argument successfully. ${ }^{48}$

\section{AREa ol MUtual InTLREST Clauses}

In Great Northern Petroleums \& Mines Ltd. v. Merland Explorations Ltd., ${ }^{49}$ an operating agreement between the parties established an AMI within which the parties were required to share opportunities and prospects. Merland was designated as the operator and acquired interests in lands outside the area of mutual interest described in the relevant agreements. The plaintiff claimed that the duty to provide notice of acquisition of lands was fiduciary in nature, and extended to include lands outside the AMI. The Court held that the parties had "expressly limited the duty with respect to acquisition of other lands to an area of mutual interest which did not include the Pacific-Imperial lands." 50 This decision was subsequently affirmed by the Alberta Court of Appeal. ${ }^{51}$

In Luscar, ${ }^{52}$ Luscar Ltd. (Luscar), Norcen Energy Inc. (Norcen) and Pembina Resources Ltd. (Pembina) were the successors in interest to a joint operating agreement. The agreement appointed Pembina as operator and provided that any party acquiring an oil and gas interest within a specified AMI had to give notice to the others. Pembina made several acquisitions within the AMI without giving notification. Norcen and Luscar commenced an action for breach of fiduciary duty, breach of trust and unjust enrichment.

The Alberta Court of Appeal held that Pembina had indeed breached the AMI clause by not giving notice. However, the expiry of the statutory limitation periods barred Luscar and Norcen's actions. The Court nonetheless proceeded to consider whether a fiduciary relationship existed on the facts. Again relying on the third part of the Frame test, ${ }^{53}$ the Court concluded that there was no inherent vulnerability peculiar to the relationship that mandated the imposition of fiduciary duties. The vulnerability apparent in the circumstances arose from Luscar and Norcen's contractual reliance on Pembina for notice. The Court ruled that, by itself, a mere contractual requirement for notice would not give rise to a fiduciary duty. 


\section{Marketing of Production}

In a number of cases, issues have arisen concerning the operator's duty to sell production and at what price. In Midcon Oil \& Gas Lid. v. New British Dominion Oil Co. Lid. and Brook, ${ }^{54}$ the parties were joint owners of a natural gas field. New British Dominion Oil Co. Ltd. (New British) was designated as the operator by an agreement between the parties. Gas was produced, but New British could not find adequate markets. Consequently, New British caused a company to be formed to purchase the gas to manufacture chemical fertilizers and became part owner of the company. The other joint owner claimed that it should be entitled to a share of the ownership in the newly formed fertilizer company. The majority of the Supreme Court of Canada found that the operator had fulfilled its duty to the non-operator to act in good faith in its efforts to sell the gas. The defendant was not otherwise inhibited, either by its agreement or by any fiduciary obligation in participating in the creation, promotion and operation of the newly formed fertilizer company.

In Erehwon Exploration Ltd. v. Northstar Energy, ${ }^{\text {ss }}$ the Court of Queen's Bench of Alberta was called upon to interpret art. VI of the 1981 CAPL Operating Procedure. ${ }^{56}$ The Court held that there was no limit imposed on the operator by clause 602 as to the use to which it may put gas which it purchases "for its own account." Therefore, the operator has a discretion as to which of the two pricing options it chooses.

The Court went on to consider whether, notwithstanding this interpretation of clause 602, the operator is subject to a fiduciary duty that would require it to sell the non-operator's gas at the same price it receives for its own gas. The operator's fiduciary obligations must be interpreted in the context of clause 602 , which authorizes the operator to purchase the non-operator's gas for its own account without any limitation as to what the operator may do with that gas. This being the case, there can be no breach of a fiduciary duty if the operator exercises that right.

A recent Court of Queen's Bench of Alberta decision, Canada Southern Petroleum Lid. v. Amoco Canada Petroleum, ${ }^{57}$ examined the marketing obligation in some detail. The agreement between the parties contained a provision to the effect that the operator would "assure the earliest feasible development and marketing of oil and/or gas found on the properties." ${ }^{\text {s8 }}$ The lands in question did not produce for many years due to lack of market and the operator's insistence on long-term sales contracts. The non-operators alleged that the operator was subject to a fiduciary obligation to develop the market and had failed to adhere to this standard. The Court was unwilling to find the vulnerability or relinquishment of selfinterest in order for the fiduciary relationship to exist.

The Court showed deference to the business judgment exercised by the defendants at the time, and concluded that the contract's obligation of "earliest feasible" marketing had been reasonably satisfied. It is reasonable to infer that an operator's marketing obligations are

(1958), 12 D.L.R. (2d) 705 (S.C.C.).

(1993), 147 A.R. I (Q.B.) [Ere/nron].

Canadian Association of Petroleum Landmen, 1981.

Supro note 48.

Jbid. at para. 2. 
typically to be strictly construed from the contract and will not be elevated to fiduciary status or expanded on the basis of a fiduciary obligation.

\section{DEALING WITH THE PROPERTy OF NON-OPERATORS}

Typically an operator receives money under an operating agreement by either making a "cash call" on non-operators where the non-operators pay a proportionate share of estimated costs or through revenue receipts from the sale of production of petroleum substances from the joint lands. In either case, the courts have pronounced that an operator is in a fiduciary position with respect to the distribution of receipts and revenues.

The Alberta Court of Appeal gave a detailed discussion of the fiduciary position of an operator in Bank of Nova Scotia v. Societe General (Canada). ${ }^{59}$ Sorrel Resources Ltd. (Sorrel) had been the operator of oil and gas properties co-owned by nine joint operators. The relationship between Sorrel and the non-operators was governed by the $1981 \mathrm{CAPL}$ Operating Procedure. Sorrel's lender attempted to enforce security on Sorrel's bank account, which included joint account funds. The non-operators objected and the Court agreed. The account contained the excess of the funds advanced by the non-operators for expenses of operating the oil and gas properties over the funds actually paid by Sorrel to cover those expenses. The account also contained the excess of the revenue recovered from those properties and still remaining in Sorrel's account over any expenses of operations paid by Sorrel under the governing agreement.

Finding the presence of a trust based on certainty of intention, certainty of subject matter, and certainty of object, Stratton J.A. held that a trust relationship did exist. The Court relied upon the right of the operator under the agreement to require the non-operators to advance their proportionate share of all costs and expenses for the joint account and the requirement that it distribute income from the sale of such production to the non-operators.

It was also held that the $198 / \mathrm{CAPL}$ Operating Procedure provision that allowed the operator to commingle its own funds with money belonging to or contributed by the joint operators was not fatal to the existence of a trust relationship. Therefore, Sorrel was not free to use the funds for its own purposes, including payment of a debt to the bank.

\section{OPERATIONS GENERALly}

In Moco Resources LId. v. Unocal Canada Resources, ${ }^{00}$ the Court of Queen's Bench of Alberta had the opportunity to consider what fiduciary duties a section operator who was also the operator and holder of a controlling interest of an adjacent unit owed to the non-operators of the section regarding production and tie-in or other transactions with the unit. The plaintiffs owned small interests in section 12. The defendant Unocal Canada Resources (Unocal) owned an interest in section 12 and was also the operator. A well was completed in section 12 but was not in production. Unocal also owned a majority interest in and 
operated the adjacent Kakwa Unit (the Unit), where there were producing wells. The plaintiffs claimed that Unocal breached its fiduciary duty as operator of section 12 .

The Court applied the Frame $e^{61}$ test for fiduciary duty, in addition to the fourth test set out in Hodgkinson. ${ }^{62}$ The Court found that Unocal owed fiduciary duties to the plaintiffs; it controlled the flow of information, there was discretionary power, and the plaintiffs were vulnerable in that they were at the mercy of Unocal in any dealings involving the Unit and section 12. Unocal had relinquished its self-interest to act in the best interests of all owners, although this conclusion is difficult to reconcile with other discussions. Unocal had breached its fiduciary duties by failing to do what was necessary and appropriate for the section 12 well to produce and for the owners to realize value for the assets. It did not recognize the conflict of interest that was making it impossible to act, as Unocal was trying to juggle its own interests with the interests of the Unit and the section 12 owners at the same time. The Court seemed to suggest that it is virtually impossible for a unit operator who is also the operator of an adjacent section not to be subject to a conflict of interest, thereby breaching its fiduciary duties to someone when potential negotiations or dealings are underway between the unit and the non-unit acreage.

Unocal's fiduciary duties ended when it resigned as operator, even though it continued to act as de facto operator, because it was no longer willing to relinquish its self-interests. Therefore, the damage calculation stopped at that date.

It is somewhat difficult to reconcile the Moco reasoning with the reasoning in the Canada Southern ${ }^{63}$ decision, where the Court of Queen's Bench of Alberta refused to import a fiduciary dimension into the operator's contractual obligation to develop a field and market the gas. Distinctions might be made between the circumstances in Canada Southern, where there was ample evidence that the operator's course of action was commercially reasonable versus Moco, where the evidence was, if anything, to the contrary.

In any event, the Moco case illustrates that the courts will, in some cases, interpret the vulnerability criterion as meaning "exposure" or being at "the mercy of the fiduciary" regarding certain assets, property, information or transactions. This interpretation of "vulnerability" potentially broadens the scope of fiduciary relationships to commercial actors of equal bargaining power acting at arm's length, as long as some exposure exists. It should be noted, however, that many courts still refuse to apply the Hodgkinson test in cases where the parties are commercial actors of equal bargaining power, such as the operator/nonoperator relationships. ${ }^{64}$

Erehwon has already been mentioned with respect to the obligations imposed on an operator when marketing the production of non-operators. However, a fiduciary obligation was found to exist under other circumstances that existed in the Erchwon case. In the view of Hunt J. (as she then was) there are:

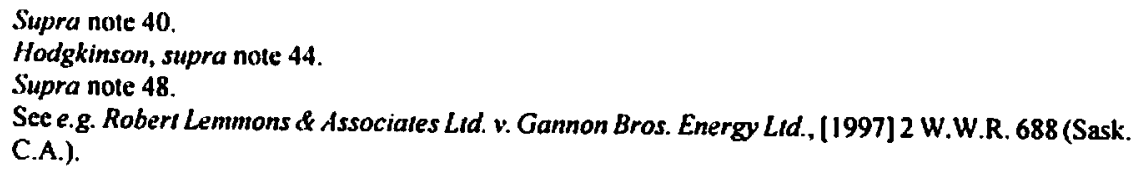


many aspects of the CAPL relationship that do give rise to vulnerability. Specifically, the operator has broad power to deal with what is the non-operator's property (including money, oil and gas that may be discovered, and facilities that may be built or acquired), with little or no supervision or involvement of the non-operator. This puts the non-operator in a vulnerable position and at the mercy of the operator. ${ }^{65}$

In Erehwon, the defendant Northstar Energy (Northstar) had charged for the operation of wells, in addition to the overheads charged under the CAPL. These fees were charged pursuant to contracts made between Northstar as contract operator (on behalf of the owners of a gas plant that it operated) and Northstar as owner (on behalf of all working interest owners). Northstar was able to establish that, in some circumstances, the fees charged pursuant to these so-called contracts were reasonable or might be reasonable in the circumstances on the basis of prevailing rates. However, Northstar was unable to establish that the costs that formed the basis of the charges to the plaintiff actually incurred.

Northstar also incurred costs in drilling wells. The drilling contractor was a wholly-owned subsidiary of Northstar's parent company. Again, Northstar was acting in a fiduciary capacity in drilling the well because it was spending joint account funds. In contracting with the nonarm's length drilling company without competitive bids and without the concurrence of the other owners, Northstar breached its fiduciary obligations.

\section{DUTY OF GOOD FAITH AND FaIR DEALING}

Canadian courts have held that "the law requires that parties to a contract exercise their rights under that agreement honestly, fairly and in good faith. This standard is breached when a party acts in a bad faith manner in the performance of its rights and obligations under the contract."

Gateway was considered by the Court of Queen's Bench of Alberta in Mesa Operating Lid. Partnerhip v. Amoco Canada Resources Lid. ${ }^{67}$ in which Mesa Opertating Ltd. (Mesa) and Amoco Resources Lid. (Amoco) were parties to a royalty agreement. Amoco's predecessor, Dome Petroleum Ltd. (Dome), purchased a number of oil and gas properties from the plaintiff. As part of the consideration for the sale of its non-producing properties, Mesa reserved to itself an overriding royalty of 12.5 percent of the gross proceeds realized upon the sale of all petroleum substances. Dome drilled a successful well on one of the acquired non-producing properties located on the south half of a section which it then pooled with the north half that it already owned in order to create a proper spacing unit. This effectively reduced Mesa's royalty interest to 6.25 percent. Mesa argued that the pooling should have occurred on a reserve basis and not an areal basis, as the gas reservoir was entirely or substantially under the south half. Although two other points were at issue in the case, the fiduciary duties issue arose in the context of the method of pooling. Mesa claimed that Dome had breached its contractual and fiduciary duties by allocating on an areal basis rather than a reserve basis. 
The trial Court refused to characterize the relationship between Dome and Mesa as fiduciary in nature because the required element of dependency (vulnerability) was not present. The Court noted that Mesa and Dome were two commercial companies acting at arm's length and that no inequality of bargaining power existed. Justice Shannon looked to the three-step Frame test confirmed by the Supreme Court in Lac Minerals ${ }^{68}$ and found that similar to the Lac Minerals case, there was an absence of the element of dependency that is essential for a finding of a fiduciary relationship. The two parties were both established oil and gas exploration companies with engineering, legal, geological and land expertise available to them for decision-making on a daily basis. No inequality of bargaining power existed between the parties.

Nonetheless, there did exist a requirement of contractual good faith that obliged Dome to consider the effect on Mesa in exercising its discretion. At the time of the pooling, Dome knew reserves were under the south half of the section. That knowledge obliged them to consult with Mesa and the failure to do so constituted a breach of the implied term of the contract obliging Dome to act in good faith.

The Court of Queen's Bench decision was appealed, and the Alberta Court of Appeal upheld the trial decision in regard to the question of fiduciary duties. In dismissing Amoco's appeal, Kerans J.A. found that

\footnotetext{
at a minimum, the reasonable expectation of Mesa and Dome/Amoco, at the time they made their agreement, was that Amoco would consider both areal and reserves-based pooling, and follow whichever route the facts justified... The rule that governs here can, therefore, be expressed much more narrowly than to speak of good faith ... a party cannot exercise a power granted in a contract in a way that "substantially nullifies the contractual objectives or causes significant harm to the other contrary to the original purposes or expectations of the parties. ${ }^{.69}$
}

This interpretation of the good faith doctrine would appear to elevate "good faith" obligations beyond merely an absence of bad faith. Leave to appeal to the Supreme Court of Canada was refused. ${ }^{70}$

\section{CONCLUSIONS}

There continues to be a judicial reluctance to import fiduciary obligations into commercial relationships. In many instances, courts seek to avoid having to deal with fiduciary issues, instead awarding or denying liability on other contractual or ethical grounds.

Canadian courts have adopted the three-fold test for establishing whether a fiduciary relationship exists as set out by the Supreme Court of Canada in Frame. The element of dependency or vulnerability is crucial to the existence of a fiduciary relationship. Recent cases and commentaries have confirmed that vulnerability should be understood not only as

Mesa Operating Lid. Partmership v. Amoco Canada Resources Lid. (1994), 19 Alta. L.R. (3d) 38 at paras. 21,22 (C.A.).

3. (1994), 162 A.R. 518 (S.C.C.) 
inequality of bargaining power, but also as exposure to opportunistic action. Furthermore, courts now tend to apply the Hodgkinson test in respect of commercial parties - the alleged fiduciary must have agreed to relinquish its own self-interest to act solely on behalf of the beneficiary.

In cases where a fiduciary relationship arises between arm's length commercial parties, the fiduciary's duties are often interpreted as being defined and limited by the terms of the agreements and the course of dealings between itself and the beneficiary.

Oil and gas operators are given a significant amount of discretion to manage, explore, develop and market production from oil and gas properties and reserves. This power does, in certain situations, give rise to fiduciary obligations; however, the obligations are generally limited to those found in the agreement. A fiduciary duty will most readily be found owed by the operator to non-operators with respect to money held by the operator in the joint account. Permission for commingling set out in the operating agreement will not negate the existence of a trust relationship, nor will a statement that the parties are tenants-in-common. Alberta courts appear to have expanded the fiduciary concept as it relates to the property of the joint account to encompass the operating relationship more broadly. In addition, it may be very difficult for an operator of two adjacent properties owned in differing interests or by different parties to avoid being accused of breaching fiduciary duties when the owners of the two properties have competing or conflicting interests. A breach of fiduciary duty may arise if an operator conducts unauthorized operations or fundamentally changes the nature of an operation without providing proper notice to non-operators. Finally, there are some circumstances in which an operator might breach a fiduciary duty by dealing on behalf of the joint account with a non-arm's length party and thereby making an improper gain to the detriment of the joint account.

\section{ASPECTS OF OIL AND GAS AGREEMENTS}

As with other aspects of oil and gas law, oil and gas agreements have evolved over time to reflect fluctuations in industry conditions and the occasional legislative or judicial intervention in industry practice. This pattern is particularly evident with regards to confidentiality clauses, indemnities, rights of first refusal and the standard of liability.

\section{A. CONFIDENTIALITY}

This section of the article deals with confidentiality agreements, both those signed for a specific purpose, such as a contemplated sale of assets or shares, and those provisions generally found in operating agreements.

The common law rules are found in the Supreme Court of Canada decision in Lac Minerals." As previously described, the majority of the Supreme Court held that the defendant in this case was in breach of a duty of confidence owed to the plaintiff, and that the appropriate remedy was the imposition of a constructive trust. The Court asserted that the existence of a breach of confidence was to be determined by establishing three elements: 
a) that the information is confidential;

b) that it was communicated in circumstances importing an obligation of confidence; and

c) that it was misused, or, in other words, used in an unauthorized way by the recipient to the detriment of the party who disclosed it. ${ }^{72}$

In Lac Minerals, the matter was complicated by the absence of a written confidentiality agreement between the parties. Confidentiality agreements are indispensable in addressing or establishing the criteria set forth above.

In developing a confidentiality agreement, there are a number of critical issues to be addressed. First, it must be ensured that the entities identified as the parties to the agreement are indeed the appropriate parties. The entity identified as the disclosing party must be the entity owning the information and, in the context of an asset sale, should be the owner of the assets. In the context of a share sale, the disclosing parties could be both the shareholder and the target company, particularly if the shareholder is disclosing information about itself, as well as information about the target.

One matter that is often overlooked in these circumstances is the matter of confidentiality subsequent to the completion of the sale. A prospective buyer should generally seek to have the benefit of the confidentiality undertakings made to other prospective buyers. Therefore, a confidentiality agreement could provide that the obligations of the recipient are assignable by the disclosing party to the person that is ultimately the successful buyer.

Of course, the agreement should require that the confidential information be kept strictly confidential. It should also state the purposes for which the information can be used and specifically prohibit other uses. It may go on to provide for specific consequences if the information is used in a particular way. For example, on occasion confidentiality agreements may provide for areas of mutual interest or they may prohibit activities in a defined area.

There will generally be limitations on disclosure relating primarily to the universe of persons to whom the receiving party may disclose the information. This list should be as restrictive as possible from the disclosing party's point of view. It would include affiliates and subsidiaries and their respective directors, officers, employees, consultants, lenders, underwriters, legal counsel, accountants and others. It should, at a minimum, oblige the receiving party to inform these other entities of the confidential nature of the information. It may oblige the receiving party to require that the other entities sign an undertaking. In addition, the agreement should, at a minimum, make the receiving party responsible for the actions of those other entities.

Confidential information will generally be defined as all information furnished by the disclosing party to the receiving party or any of its representatives if that information relates to the disclosing party, the target company, or the target assets. It can also include the fact that the confidentiality agreement has been signed, and that the parties may enter into 
discussions concerning a sale. In regard to this latter element, it could be important to the receiving party that the disclosing party also undertake to maintain that fact in confidence.

The definition will be subject to exceptions. The first of these exceptions will be information that is or becomes generally available to the public. The second exception would relate to information already known to the receiving party, but the exception should be limited to such information only if it was known on a non-confidential basis. The third exception would pertain to information that becomes available to the receiving party on a non-confidential basis in the future.

A fourth exception that often appears in the definition or elsewhere in the agreement is a provision that permits the receiving party to make required disclosures. These requirements can arise under statute, under regulations made pursuant to a statute, and under the rules of a stock exchange. They may also arise by virtue of the orders or policies of a securities commission. Unless the receiving party clearly has no choice as to disclosure, it is generally prudent to require that there be consultation between the parties prior to release of the information or the issuance of press releases. Many agreements contemplate the possibility that a party will be required by court order to disclose information.

Confidentiality agreements generally make it clear that the confidential information remains the property of the disclosing party and that it will be returned to the disclosing party upon request. The agreement may also require that the receiving party destroy any copies it has made (presumably including any files downloaded from a website) and any notes, evaluations or interpretations. This requirement can be accompanied by a requirement that an officer of the receiving party certify in writing that he or she has complied with these obligations.

The agreement should state very clearly the purpose for which the information can be used by the receiving party. As mentioned above, the agreements can provide for areas of mutual interest and similar mechanisms specifically to allow for the patriation by the disclosing party of some or all of the benefits realized by the receiving party.

The majority of confidentiality agreements contain a provision that deals with remedies. Generally, the disclosing party will want the receiving party to agree that any damages alone would not be a sufficient remedy for a breach of the agreement by the receiving party or its representatives, and thus the disclosing party will be entitled to specific performance and injunctive relief as remedies. The reason for this, of course, is that one of the elements necessary to establish entitlement to an injunction is that monetary damages are an insufficient remedy. Contracts often purport to specify the remedy available upon breach. There is, however, relatively little authority on the weight that the courts are prepared to give to contractual terms expressly stipulating specific relief. While such clauses appear to be common in the case of personal service contracts, the effectiveness of providing for injunctive relief in the event of a breach of a non-competition clause in commercial contracts is difficult to assess. Sharpe ${ }^{73}$ and other commentators are of the opinion that where a freely bargained contract provides for specific performance or injunctive relief, and the contract has 
allocated the risk of the event making performance undesirable to the defendant, the clause stipulating specific performance or injunctive relief to enforce a positive covenant should be enforced.

The confidentiality obligations in the 1990 CAPL Operating Procedure ${ }^{74}$ are found in art. XVIII. This permits parties to use information for their sole benefit. The article does not explicitly permit the disclosure of information to current or prospective lenders or prospective transferees. It only permits the disclosure to a third party 10 whom it has been permitted to assign a portion of its interest. A covenant must be obtained from the third party to the effect that none of the information will be disclosed by it to any other third person. What is odd about this provision is that it speaks in the past tense by using the phrase "has been permitted," which would suggest that since the consent or right of first refusal provision would not have been complied with at the time a data room is opened, disclosure to a perspective transferee is in fact not permitted. What is also odd is that once the disposition to a specific third person is permitted, novation into the operating agreement should be sufficient to bind that purchaser to the confidentiality provisions in the operating agreement, such that the binding covenant referred to in $\mathrm{s} .18 .01$ (c) would be unnecessary. Disclosure to consultants is permitted, but disclosure to current or prospective lenders and underwriters is not.

\section{B. INDEMNITIES}

Perhaps because they can be found in almost every oil and gas contract, indemnities are often shrugged off as boilerplate and not worth the time and fees to tailor them to a particular agreement. But there is no one indemnity clause that can address and satisfy all concerns irrespective of the transaction. If their actual content and effect are not carefully addressed, indemnities can end up creating more uncertainty and litigation than they eliminate.

\section{HOW AND WHERE DO INDEMNITIES ARISE?}

Most indemnities in the oil and gas industry are contractual in nature. As such, they are governed solely by their terms and by basic contract law. However, indemnities can also arise in equity if a person incurs an expense or is exposed to a liability as a result of acts done at the request or order of another person. Examples of situations where equitable indemnities might be found include agency relationships, trustees, partnerships and the relationship between directors/officers and corporations.

\section{INDEMNITY COMPARED TO OTHER CONTRACTUAL RISK-MANAGEMENT TOOLS}

Although the terminology is often wrongfully interchanged, an indemnity differs from a guarantee in some important respects. Most importantly, a guarantee is a secondary obligation of a guarantor that depends on the existence and validity of a primary obligation between the principal debtor and the creditor. A guarantee will only be triggered if the principal debtor does not perform the obligation (usually to pay a monetary amount) that it owes to the creditor. By comparison, an indemnity is a primary obligation of the party giving 
the indemnity (the "indemnitor") to compensate or make whole the party who gets the benefit of the indemnity (the "indemnitee") if the indemnitee suffers a loss covered by the terms of the indemnity. As an example, most insurance contracts are contracts of indemnity.

An indemnity is not the same as a contractual representation or warranty. These are interparty promises which by law give rise to a claim for damages or other relief only if they are breached. By comparison, an indemnity does not require a breach of its terms or any other contractual terms to be triggered; all that is required is the occurrence of a covered event that causes a quantifiable loss. Furthermore, unlike contractual representations that usually only impose liability for damages suffered by the contracting parties (the principle of privity of contract), indemnities can impose liability for direct losses of non-contracting parties. Indemnities can also compensate for losses not recognized or commonly awarded at common law (for example, solicitor-and-own-client costs or losses caused by a party's own negligence) to which a breach of a contractual representation will not normally lead.

\section{ISSUES TO CONSIDER IN DRAFTING INDEMNITIES}

Traditionally, indemnitors were only liable for third party claims against the indemnitee. However, indemnities are now used to cover the indemnitee's direct losses, not just those that arise $v i s-\dot{a}$-vis third parties. A recent case showing how a properly worded indemnity can do this is TransCanada Pipelines Ltd. v. Potter Station Power Ltd. Partnership ${ }^{75}$ In that case, TransCanada Pipelines (TCPL) and Potter Station Power Ltd. (Potter) had entered into an agreement whereby Potter would build an electrical generating plant on lands adjacent to a TCPL compressor station. TCPL had the benefit of an indemnity granted by Potter covering, among other things, the construction, operation and maintenance of the plant and Potter's negligence incidental to the agreement. During the operation of the plant, water was drawn from an aquifer under TCPL's compressor station. The lands subsided, causing damage to the compressor station and its equipment.

Justice Lane stated that "the case law does not establish a general principle that wherever words of indemnity are found, the obligation created is confined to responding to claims made against the indemnitee by third parties." ${ }^{176} \mathrm{He}$ then turned to the actual context and wording of the indemnity, which stated that Potter was obligated to "indemnify and save harmless TransCanada from and against all liability, actions, claims, losses, costs and damages which might be brought against or suffered by TransCanada."" In Lane J.'s opinion, this was clearly evidence that more than just third party claims were covered.

What if the indemnitee causes itself a loss through its own negligence? There is case law that suggests that an indemnity requires clear and strong language if an indemnity is to extend this far. $^{78}$

TransCanada Pipelines Lid. v. Potter Station Power Lid. Parmersitip (2002), 22 B.L.R. (3d) 210 (Ont. Sup. $\mathrm{Ct}_{\text {.). }}$.

\% Ibid. at para. 35

$n \quad$ Ibid. at para. 21

7n See e.g. Travellers Indemnity Co. of Canada v. Werner (1985). 37 Alta. L.R. (2d) 92 (C.A.). 
What if the indemnitor suffers a loss caused by the indemnitee? Will the indemnity clause provide the indemnitee with a defence against a potential claim brought against it by the indemnitor? The case law suggests that an indemnity clause alone will not, and that a separate limit of liability clause or other undertaking of the indemnitor's not to sue the indemnitee is required. In Erehwon, ${ }^{79}$ the argument that the indemnity clause in the 1981 version of CAPL's Joint Operating Agreement ${ }^{80}$ protected the operator from a claim by the nonoperators with respect to an accounting error by the operator was strongly rejected.

This decision was followed in Morrison Petroleum Lid. v. Phoenix Canada Oil, ", which involved an Operator looking to the indemnity in the 1981 CAPL Operating Procedure ${ }^{82}$ for protection against the Non-Operator's claim that it did not conduct the drilling operations "in accordance with good oilfield practices," as was required under the terms of the Operating Procedure. Justice Moshansky stated:

Clearly, if the [Operator] had intended that the [Non-Operators] were to relieve it from liability for losses caused by its own negligence, other than third party claims, that could have been accomplished by requiring from the [Non-Operators] an undertaking in the Participation Agreement not to sue for anything except wilful or gross negligence. ${ }^{83}$

Similar in this respect to an insurance policy, an indemnity can be tailored to only cover certain categories of losses. There is merit in explicitly mentioning some categories of loss, such as costs for legal counsel (on a solicitor-and-own-client basis), consultant fees, loss of profits and other losses that a court might decide are not covered by general wording in an indemnity. Alternatively, one may wish to exclude certain types of losses and damages, such as lost profits.

An indemnity can be structured so that the indemnitor is not on the hook for 100 percent of the damages. By imposing a monetary threshold of damages or a cap, the indemnitee remains responsible for small losses or for a portion of huge losses. A threshold saves the indemnitor from having to pay for more common and hard-to-avoid losses, and a cap provides a limit to the indemnitor's exposure. With no cap, either by way of a dollar figure or the types of damages covered, an indemnity will apply to any and all losses that can be attributed by ordinary legal principles (causation, remoteness or public policy) to the event in question.

Sometimes, a party may think that it has negotiated the added protection of an indemnity for itself, when it has actually put itself in a worse position. It is common to see, in more words or less, indemnity clauses that state that the only route to a remedy for a breach of the agreement is through the indemnity. Then the clause lists a number of conditions that, if not met, make the indemnity unavailable. Typical conditions include burdensome notice provisions and a shortened indemnity lifespan.

\footnotetext{
7i) Supra note 55.

2. Canadian Association of Pelroleum Landmen, 1981.

" (1997), 198 A.R. 81 (Q.B.) [Morrison].

k2 Supra note 56.

*. Morrison, supra note 81 at para. 92.
} 
Can an indemnitee simply let its damages mount, knowing that the indemnitor is on the hook? In Canada, the issue has not been clearly settled, but there likely is a duty to mitigate. ${ }^{8.4}$ Nonetheless, it is worthwhile to eliminate any uncertainty by explicitly stating that the indemnitee has a duty to mitigate its losses where it can. This is also advisable where Canadian laws may not govern the contract, as some other jurisdictions (the United Kingdom being the most relevant example) do not impose a duty to mitigate on indemnitees.

In drafting an indemnity clause, it is worthwhile to consider whether the indemnity should only cover a loss or the portion of a loss not covered by the indemnitee's insurance policy (or policies) required under the agreement. This would not only limit the indemnitor's risk, but also would remove the insurance company's right (by way of subrogation) to go after the indemnitor to recoup any payments made under the policy. It also would remove the indemnitee's option of not filing a claim with its insurer to avoid having its premiums go up and instead simply looking to its indemnitor.

If such a term was not expressly provided in an indemnity, an indemnitor would not be able to resist paying the indemnitee, even if the loss was covered by the indemnitee's insurance policy. Equally, the indemnitor would not be able to later resist the insurance company's claim for repayment of monies paid to the indemnitee under the policy.

Indemnitees should remember that even if the option remains available first to pursue the indemnitor rather than the insurer, the indemnitee should immediately notify its insurer of the potential claim so that if the indemnitor fails to indemnify, the indemnitee will not have lost its rights under the policy.

Giving an indemnity (being an indemnitor) might affect the indemnitor's insurance. A loss paid out under an indemnity could possibly be one that would not be covered by a regular policy. This would be especially true if the indemnity was not disclosed to the insurer, as the insurer would not have an accurate idea of the degree of risk.

\section{RIGHT OF FIRST REFUSAL ISSUES}

The jurisprudence on legal issues pertaining to rights of first refusal (ROFRs) has evolved step-by-step over the last two or three decades. The courts have refined their approach to the issues and, consequently, the petroleum industry in Canada has benefited from the increased certainty. Although the trend has been towards a decline in the use of ROFRs in joint venture relationships, the subject remains an important one by reason of the costly consequences associated with breaches of ROFR provisions.

Although the common law still regards a ROFR as a contractual right of a personal nature that is not an interest in land, certain jurisdictions such as Alberta and British Columbia have established by statute that ROFRs on land are interests in land. ${ }^{85} \mathrm{As}$ a result, ROFRs in Alberta can be caveated, and failure to do so might subject the 
ROFR holder to be defeated by a bona fide third party ROFR holder who subsequently caveats such right without notice of the first ROFR.

- In several decisions, ${ }^{86}$ the courts appear to take the view that ROFR provisions dealing with triggers and exceptions must be construed in a purposive fashion. Without valid business reasons, parties cannot avoid the application of a ROFR by structuring a transaction to achieve indirectly what they cannot do directly. Therefore, "butterfly" and other corporate reorganizations might trigger ROFRs if their sole or main purpose is to avoid the pre-emptive right.

- The industry agreements generally provide that ROFR provisions dealing with notice and acceptance must be strictly complied with to be effective and valid. ${ }^{87}$ Invalid notices can produce disastrous results for a transaction including delays, termination and, in the worst-case scenario, post-closing litigation involving damages, unwinding of the transaction, and/or specific performance.

- Both industry agreements and the preponderance of case law ${ }^{88}$ reflect the view that where a property subject to a ROFR is sold for a consideration that cannot be matched by the ROFR holder, the offeror must attribute a bona fide cash value to the property. If the property is part of a larger sale package, the offeror must allocate a cash value to the property.

- Specific performance may be granted to a ROFR holder against both the vendor and the third party purchaser in circumstances where the third party is not a bona fide purchaser without notice of the ROFR.

- Injunctive relief is also available to ROFR holders whose rights have been infringed. However, the tripartite test for injunctions (serious issue to be tried, irreparable harm and balance of convenience) must be satisfied, and the courts seem reluctant to grant injunctions in cases where the ROFR language in dispute is ambiguous.

\section{The Gross Negligence Standard}

A major development in oil and gas joint venture issues has been the movement away from the "prudent operator" standard for joint operations toward the "gross negligence or wilful misconduct" standard adopted in the 1990 CAPL Operating Procedure ${ }^{89}$ and generally throughout the industry since.

Under the 1981 CAPL Operating Procedure, the operator had to conduct operations "diligently, in a good and workmanlike manner, in accordance with good oilfield practice." Case law has interpreted such standard to be the "prudent operator" or "reasonable man" standard used in the general law of simple negligence."

See GATX Corp. v. Haw'ker Siddeley Canada (1996), 27 B.L.R. (2d) 251 (Ont. Ct. J. (Gen. Div.)); Chase Manhattan Bank of Canada v. Sunoma Energy (2002), 317 A.R. 308 (C.A.).

See CAPL Operating Procedure, supra note 45, s. 2401 (b).

See Manchester Ship Canal Company v. Manchester Racecourse Company, [1901] 2 Ch. 37 (C.A.);

Canadian Long Island Pertroleums Lid. v. Irving Indusiries, [1975] 2 S.C.R. 715.

Supra note 74.

Supra note 56.

Aarland and Aarland v. Taylor, [1955] O.R. 131 at 142 (C.A.). 
The 1990 CAPL Operating Procedure exempts the operator from liability, whether contractual or tortuous, unless it has committed "gross negligence or wilful misconduct." This standard has been interpreted by the courts as meaning:

a very marked departure from the standards by which reasonable and competent companies in a like position should govern themselves; or a conscious indifference to the rights or welfare of persons affected by it. ${ }^{93}$

Under the 1990 CAPL Operating Procedure, such a standard applies to breach of contract as well as to tortious acts or omissions of the operator. Practically speaking, it seems to apply to accounting as well as operational practices. It also has been adopted in many non-CAPL agreements.

\section{International Petroleum Agreements}

\section{A. The Evolution of Contract Structure IN THE International Petrolegum Context}

The nature of the agreements entered into between host governments and international oil companies for the exploration, development and production of petroleum substances over the last 100 years can be characterized by one word: dynamic. The purpose of this section of the article is to briefly describe the evolution of the contract structure used in international petroleum transactions and to examine the new structures currently being proposed by host governments. From this analysis, the authors hope to make abundantly clear that the pendulum of influence concerning the participation in, and control of, the conduct of petroleum operations in respect of the host government has swung from a point of little or no influence and control to almost absolute control. The degree to which these new contract structures will be accepted by international oil companies is uncertain.

\section{InItial Contracting Structure - The Concession Agreement}

The concession type of agreement is the oldest and the most commonly used form of agreement in use in more than 121 countries. The summary below probably most accurately describes the circumstances surrounding the early concession agreements:

It must be recalled that in those days, concessions were granted by Sovereigns with sometimes little authority. offen under foreign political dominance. Also, the countries concerned were backwards, sometimes nomadic, and in no case possessed a legal framework liable to govern such things as petroleum operations. Therefore. in order to fill that void, concessions were not only tilted in favour of IOCs but also written in such a way that they constituted self-sufficient charters for those areas of the world where existed no infrastructure of any kind, nor any government control or capabilities of any son. ${ }^{94}$

Keith W. Blinn et al., International Petroleum Exploration \& Exploitation Agreements (New York:

Barrows, 1986) at 60. 
The earliest concessions transferred all managerial and decision-making rights over the conduct of petroleum operations to the international oil company. In exchange, the host government was usually given an initial payment and a right to some small fraction of the value of any oil produced.

Geographically, the original concessions generally covered large areas. The concession granted to William Knox D'Arcy by the Persian Government in May 1901 was for the whole extent of the Persian Empire with the exception of its five northern provinces and covered in excess of 500,000 square miles. The original concessions granted in Kuwait and Abu Dhabi covered their entire countries.

The term of the concessions were usually quite long, rarely less than 60 years. The Saudi Arabia concession had a term of 66 years, and the Abu Dhabi and Kuwaiti concessions had terms of 75 years.

Essentially, the major characteristic that distinguishes a concession agreement from any of the other forms is that ownership of all production is vested in the oil company, subject to a royalty (payable in kind or in cash) and a tax on profits. As the host government has no right to take any share of production, the royalty and tax regimes are usually higher than under any other form of agreement.

\section{The Production-Sharing CONTRACT}

With the end of World War Il, the demand for oil production worldwide grew immensely. In this regard, although the industry was previously dominated by the "Seven Sisters" (Gulf, Texaco, Mobil, Standard Oil of California, Exxon, Royal Dutch Shell and British Petroleum), oil companies that had previously focused only on United States domestic opportunities entered the international petroleum arena. With the influx of additional oil companies, competition for the underlying reserves increased. With this increase in competition, host governments took the opportunity to advance their interests in petroleum exploration and development. A significant number of countries enacted general petroleum laws under which smaller and more numerous concessions of shorter duration were granted to many companies. Host governments increased royalties and taxes on oil production and began to demand increased participation in the decision making process. Perhaps the most significant evidence of this shift in control occurred when the Indonesian government passed Law $\# 44$ in 1960," proclaiming that all foreign oil companies operating in Indonesia would henceforth be contractors of the state and would not hold concessions. Disputes had arisen between the government of Indonesia and the three major oil companies concerning the status of the companies' existing concessions, marketing price controls and the failure of the government to grant new concessions. The companies regarded Law \#44 with serious concern, not specifically with respect to its Indonesian operations, but with respect to the impact that it could have on worldwide operations if this amendment was allowed to proceed. Accordingly, the companies refused to accept Law \#44 and negotiations started in an effort to reach a settlement. After numerous discussions, the Indonesian government decreed that if an agreement was not reached within a specific time frame, all of the companies operating 
within Indonesia would be nationalized. The American government then became involved and succeeded in mediating a new form of contract which was referred to as a "Contract of Work." Under these agreements, the companies assumed the new status as "contractors," but maintained management control. Production was allocated 60 percent to the Indonesian government and 40 percent to the oil companies. This contract structure ultimately resulted in what we currently understand to be a production-sharing contract.

The essential difference between a production-sharing contract and a concession agreement is that the production-sharing contract allocates production between the host government and the international oil company. It is common in these circumstances that a portion of production is set aside so as to allow the international oil company to recoup those costs and expenses incurred in the conduct of exploration and development activities. The characterizations resulting from this allocation process are commonly referred to as "cost recovery production" and "profit sharing production."

The production-sharing contract structure has thus been in place in excess of 40 years. Throughout this time, host governments have increased their participating rights and understanding of the petroleum industry. Today, some of the largest corporations involved in international petroleum exploration and development are the national oil companies of these countries. In light of the foregoing, the technical expertise usually restricted to the intemational oil company is now also held by the host government. In effect, the absolute requirement for international oil company participation has begun to diminish. Today we are seeing the full effect of the change in negotiating power with the use of risk service agreements and even service agreements in petroleum transactions.

\section{RISK SERVICE: AGREEMENTS}

As evidenced by the name, risk service agreements document transactions pursuant to which the host government contracts for the technical, financial and commercial services of the international oil company. If production is encountered, the international oil company is reimbursed for the costs of its services and is provided with some form of additional compensation. The basic feature of a risk service agreement is that the international oil company is usually reimbursed in cash and not in crude oil for its costs of exploration and development, although there may be some provisions that permit the oil company to purchase crude oil by a credit of its cash payment based on some discounted pricing formula.

Historically, the risk service concept was slow to gain any acceptance by the international oil company. Originally conceived in the early 1960s, it was not until 1976 when this form of agreement became accepted as the mechanism for development and production operations in Brazil. This contract structure is now in use in approximately 5 percent of the petroleumproducing world.

Risk service agreements are similar in principal to production-sharing agreements. The main difference lies in the manner in which costs are reimbursed and the international oil company is compensated for its services. Essentially, the international oil company is contracted to perform certain services as a "contractor" of the host government. In the event of commercial production, the international oil company is compensated through a 
reimbursement and remuneration calculation. Absent commercial production, the financial risk is born by the international oil company that would receive no reimbursement and no compensation for its services.

Recently, the concept of a risk service agreement has become popular in countries where, due to a constitutional or other legal restriction, international oil companies are prevented from participating in petrcleum exploration, production and development opportunities. Other countries have utilized the risk service concept to attract financing while still maintaining ultimate control over the development of their petroleum resources. Kuwait is an example of a country utilizing the risk service structure due to constitutional and other legislative restrictions. Iran and Iraq are examples of countries utilizing the risk service structure in order to maintain operational control of petroleum development. Mexico is using a service contract model.

\section{Kuwait Modil. Petroleum Agreement}

In November 1999, an international conference ${ }^{96}$ was held in Kuwait to discuss the type of agreement that will be used for Project Kuwait. This project involves production enhancement operations in respect of four fields currently producing 400,000 barrels of oil per day. Target production in five years through water injection and gas lift is expected to be 900,000 barrels of oil per day. Specific production targets were established for the North Kuwait oil fields in 1995. Subsequently, Kuwait Oil Company concluded that these targets could not be achieved without international oil company assistance. Key objectives for the project were established to achieve strategic production targets for the North Kuwait fields, maximize reserves though effective reservoir management practices, develop more difficult reservoirs and acquire and implement the technologies required for secondary recovery and enhanced oil recovery projects. Other objectives included cost savings and improved capital efficiency, training and job opportunities for Kuwaitis to acquire modern management techniques and encouragement of strategic and economic ties with international oil companies. The relationship with international oil companies had to be consistent with Kuwait's constitution, which clearly states that hydrocarbon reserves and the revenues therefrom must be controlled solely and exclusively by the State. Kuwait was required to retain ownership of all petroleum produced and revenues therefrom, and title to crude oil and gas could not be transferred in the international oil companies. The service-type relationship was determined by the Kuwait Government to be the best for meeting the objectives of Kuwait and, in this regard, the concept of an operating service agreement was developed.

\section{THE REPUBLIC OF IRAN MODEL - "SERVICE CONTRACT" OR "BUY BACK CONTRACT"}

Article 81 of the Iran Constitution provides: "The granting of concessions to foreigners for the formations of companies or Institutions dealing with commerce, industry, agriculture,

\%. Conference on "The Role of International Oil Companics in the Development of Oil Fields in Kuwait," Kuwait. November 1999. 
services or mineral extractions, is absolutely forbidden." 97 As a consequence of this constitutional limitation, Iran developed the buy-back contract that can be described as a contractual arrangement whereby the international oil company agrees to bear the financial burden and technical risk of developing a hydrocarbon reservoir for a predetermined fixed fee. The international oil company, on satisfactory technical due diligence, agrees to a scope of work and budget to develop a field project. It then operates the field until project commissioning. The National Iranian Oil Company operates the field after commissioning. During an agreed amortization period of five to eight years, the international oil company receives:

- Investment costs plus interest at London Interbank Offered Rate Index (LIBOR) plus an agreed uplift; and

- a remuneration fee.

The "Buy Back Model" has a limited economic upside and unlimited potential economic downside:

- technical risk, cost and schedule of development

- reservoir risk

- management committee risk; and

- political risk

\section{REPUBLIC OF IRAQ}

As a result of the Iran-Iraq War and the subsequent introduction of United Nations (U.N.) sanctions arising out of the Gulf War, Iraq's ability to produce and maintain its petroleum resources was significantly hampered. To address the problem, the Republic of Iraq sought to attract foreign investment to explore for and develop petroleum resources. At the outset, it was thought that the sanction regime would last between two and five years, and that petroleum operations by international oil companies would be permitted thereafter. To address the potential for foreign investment, the Ministry of Oil of the Republic of Iraq developed a production-sharing contract model that it used in initial negotiations. When U.N. sanctions were not removed within the anticipated timeframe, the Ministry of Oil began to develop further model contracts to address exploration and development in the Republic of Iraq. A risk service contract and a modified buy-back contract resulted.

The initial form of risk service contract was based on the production-sharing contract model with specific amendments to address recovery of costs and a guaranteed fee paid to the international oil company.

Under the modified buy-back contract, the international oil company was required to finance all of the applicable exploration and development expenses and was reimbursed for its capital, operating and banking charges from production revenue. In addition, it was granted a guaranteed fee. Operatorship of the field transferred to an Iraqi entity once a 
specific production plateau was achieved. The compensation was repaid over a three year period, after which the international oil company no longer had any interest in the field.

\section{MEXICO}

Pursuant to the Mexican Constitution, foreign ownership of all natural resources, including hydrocarbons, is vested in the Nation. Under the Petroleum Law of 1958, the definition of "petroleum industry" was expanded to include exploration, refining, transportation, storage, distribution and the initial sale of all petroleum and natural gas. ${ }^{98}$ It further provided that the Mexican national petroleum company, PEMEX Exploracion y Produccion (PEMEX), could only grant performance- and incentive-based contracts, provided that no ownership rights over the petroleum was granted to the contractor. Recently, however, the Mexican Congress has enacted certain amendments that allowed for private participation in transportation, storage, distribution and marketing of natural gas. The Mexican Government has now decided to allow some form of private investment in the development of non-associated natural gas fields. In this regard, the government has sought to introduce a "multiple services contract" program with the following characteristics:

- The multiple services contracts program apparently does not contravene existing statutory provisions as all activities are conducted on behalf of PEMEX, and the contractor is paid a defined fee;

- The intent of the multiple services contract program is to integrate a host of services under one contract, with one contract or consortium for each contract area;

- The contractor will be paid for its services in U.S. dollars;

- The contractor will have no right or interest in any oil or gas nor will they have any right to explore for or produce same; and

- Each contractor will be responsible for all capital and operating costs and will recoup these costs and a profit if and when there is incremental production.

\section{CONCLUSION}

Countries with significant petroleum reserves have adopted contractual structures that limit or eliminate the financial returns historically enjoyed by international oil companies as compensation for undertaking the various risks associated with petroleum exploration and production. For Mexico, Iraq and Kuwait, it is too early to tell if these will be acceptable to companies and their stakeholders. The Iranian structure has been begrudgingly accepted, but the industry is starting to push back by requiring amendments and a number of the world's largest petroleum companies have avoided participation in Iran all together. Only time will tell if these structures will be adopted by the international oil companies and if the structures will find their way to other host countries. With industry consolidation and the number of companies pursuing international petroleum opportunities decreasing, the pendulum may be about to swing in favour of the companies. 


\section{B. The 2002 alPN Model Operating Procedure: A Summary OF Significant Cilanges}

The Association of International Petroleum Negotiators (AIPN) first released its Model Form International Operating Agreement in $1990 .{ }^{99}$ The 1990 version was subsequently revised in $1995 . .^{100}$ In an effort to address continuing legal developments and changing industry practices, the AIPN began the process of revising the 1995 Model Form International Operating Agreement in January, 2001. The final product, the $2002 \mathrm{Model}$ Form International Operating Agreement ${ }^{101}$ reflects the efforts of over 90 AIPN JOA Revision Committee members on virtually all continents, as well as the valuable contribution of many other AIPN members. This section of the article will describe the major revisions made to the $2002 \mathrm{JOA}$ in order to facilitate its use as a model form in the industry.

\section{OPERATORShIP (ARTICLE 4)}

The standard of care owed by an operator in connection with joint operations refers consistently to the "good and prudent practices generally followed by the international petroleum industry under similar circumstances."102

In 2001, commentators in the AIPN Advisor confronted the issue of whether the wording of the gross negligence threshold in art. 4.6 of the $1995 \mathrm{JOA}$ acts to shield the operator from liability vis-à-vis its co-ventures for the operator's breach of the JOA. In effect, the argument was that art. 4.6 could conceivably be used to shield an operator for cost overruns, failures to share information under art. 4.4, improper abandonment of a well, improper settlement of a lawsuit, and other similar breaches of contract relating to the functions and duties of the operator under the operating agreement. There was no consensus on appropriate replacement language.

Since wilful misconduct is utilized under English law as opposed to gross negligence, the defined term Gross Negligence/Wilful Misconduct was developed to facilitate the document's use under English law. An optional provision was added allowing the operating Committee to direct the operator to deposit monies received for the joint account in an interest-bearing account. The opportunity is available for each party to underwrite some or all of the requisite insurance to be procured on behalf of joint operations through such party's affiliate or captive insurance company.

An option was added to art. 4.7 permitting the operator to self-insure with respect to its obligations to procure insurance for joint operations. In the event that such an election is made, the operator must notify the Operating Committee and provide a qualified selfinsurance letter setting forth the coverages to be self-insured. 


\section{SfCONDMENT (ARTICI.F 4.3)}

The $2002 J O A$ now reflects an emerging practice pursuant to which non-operators assist the operator in the conduct of the joint operations by the provision of secondees. Specifically, "secondment" is defined as the placement within the operator's organization of one or more persons who are employed by a non-operator or an affiliate.

Secondment of non-operator personnel is now addressed in the 2002.JOA in two of three alternatives under art. 4.3. The first alternative does not authorize the operator to use secondees. The second alternative does authorize use of secondees, but without imposing on the parties any procedure to propose secondment or select secondees. The third alternative sets out detailed procedures with various options with respect to the level of the operator's discretion to select and integrate non-operator secondees into the operator's organization. An important aspect of art. 4.3 concerns the limitation of liability for the non-operator providing such secondee. It is conceivable that the non-operator employer of the secondee and the secondee himself may be liable for the secondee's mere negligence, absent some modification to the definition of "Indemnitees" under art. 4.6 or specific allocation of liability in the separate secondment agreement.

\section{Health, Safety and EnVironment (ArTicle 4.12)}

A specific Health, Safety and Environment (HSE) provision has now been incorporated into the $2002 \mathrm{JOA}$. This provision contains alternatives to reflect the diverse manner in which HSE issues have been addressed by various operators in the context of international operations. At a minimum, however, the alternatives obligate the operator to develop and implement an HSE plan that is consistent with local HSE laws, regulations and, the standards and procedures generally followed in the international petroleum industry.

\section{Operating Committee (ARTicle 5)}

Each party now has the express right to appoint a representative to each sub-committee to ensure that subcommittees mirror the Operating Committee. ${ }^{103}$

The $2002 J O A$ also requires that notice of Operating Committee meetings or the request of vote by notice includes copies of all proposals to be discussed with the necessary supporting documentation relevant to such proposals.

The defined term "Urgent Operational Matters"104 was added to the $2002 \mathrm{JOA}$ for those situations requiring an expedited vote of the Operating Committee. An expedited vote is now available for all operational matters reasonably considered by the operator to require, by their nature, urgent determination. 


\section{BUDGET AND AUTHORIZATION FOR EXPENDITURE (AFE) (ARTICIE 6)}

The operator's contractual obligations are often undertaken on a multi-year basis. To address this reality, the $2002 \mathrm{JOA}$ now provides for multi-year work programs and budgets.

An interesting change from the $1995 \mathrm{JOA}$ was made to address the option allowing for total deletion of the AFE requirement. The rationale for this change is that in the conduct of international joint operations it is not a uniformly accepted industry practice to require the use of AFEs.

\section{EXCLUSIVE OPLRATIONS (ARTICLES 5.13 AND 7)}

The $1995 \mathrm{JOA}$ provided for two forms of compensation to allow for the subsequent participation of a non-consenting party in an exclusive operation: an in-kind premium and a cash premium. The in-kind premium formerly included in art. 7.4 has been deleted by the Revision Committee due to a consensus that it was rarely, if ever, selected. Instead, the parties can now elect under art. 7.5 to have a non-consenting party pay its premium (including past costs) through disproportionate spending, an approach that is often used in farm-out agreements with a view to obtaining tax advantages for the consenting parties.

A significant revision with regard to exclusive operations was added under art. 5.13(B), permitting the parties that first consented to an exclusive operation (or were not allowed to non-consent) to revisit their decision in light of the other parties' notice of non-consent after a first favourable vote by the Operating Committee.

\section{DEFAULT (ARTICLE 8)}

Recent case law has held that, in certain circumstances, requiring a party to forfeit its entire participating interest is an unenforceable penalty. The $2002 \mathrm{JOA}$ now includes in art. 8.4 an alternative (the buy-out alternative) that allows negotiators to avoid completely the forfeiture enforceability issue.

Under the buy-out alternative, a valuation of the defaulting party's participating interest is established in one of two ways:

the defaulting party can accept the value proposed by the acquiring parties; or the defaulting party can seek an expert determination of the value under art. 18.3.

The defaulting party no longer has:

the right to transfer all or a portion of its participating interest, except to a nondefaulting Party:

the right to consent, reject, or exercise any other right in connection with a transfer under arts. 8 or 12 ;

the right to withdraw under art. 13; or

the right to take an assignment of another party's participating interest in the event that such other party is either in default or withdrawing. 


\section{Crude Oll and Gas Disposition (ARTicle 9)}

The provisions contained in art. 9.2 have been expanded to address the party's rights and obligations to take and dispose of crude oil and natural gas production. The $2002 \mathrm{JOA}$ provides for four alternative arrangements for the off-take of crude oil, including an alternative reference to the AIPN Model Form Lifting Procedure. ${ }^{105}$

The $2002 J O A$ greatly expands on the provisions relating to the treatment of a gas discovery. The $1995 \mathrm{JOA}$ contained a one line gas provision that has now been expanded to over three pages. ${ }^{106}$ Notwithstanding this increase in detail, the gas provisions in art. 9 only outline the basic principles commonly agreed to in the international petroleum industry. Alternative 1 in art. 9.3 contemplates utilizing a gas balancing agreement and a multi-party gas disposition agreement. The multi-party gas disposition agreement recognizes the fact that, in a number of jurisdictions, there is no developed natural gas market and thus a common stream disposition is necessary or preferred in order to monetize the resource. Care must be taken in implementing the multi-party gas disposition agreement due to anti-trust and trade practice concerns as well as the ramifications of the host country laws.

\section{PRE-EMPTIVE RIGHT AND RIGHT OF FiRST NEGOTIATION}

An optional provision was added to permit the parties to restrict pre-emptive rights or right of first negotiation to cash transfers only. Cash transfers are defined as transfers where the sole consideration, other than the assumption of obligations, is in the form of cash, cash equivalents, promissory notes or retained interests.

One clarification to the pre-emption clause that might be overlooked is that it is no longer necessary to disclose all terms of the proposed transfer to the other parties. The proposed transferor is now only obligated to disclose "[s]uch final terms and conditions as are relevant to the acquisition of the Participating Interest." 107

In dealing with package or non-cash sales, the $2002 \mathrm{JOA}$ incorporates the defined term "Cash Value" in lieu of the "reasonable and justifiable cash value" standard that was previously employed. ${ }^{108}$ Cash Value can be defined in one of two ways:

(i) total monetary value to the transferor, which includes cash, other assets and potential tax savings that may arise in a non-cash deal; or

(ii) market value of the Participating Interest, based on the cash a willing buyer would pay a willing seller in an arm's length transaction.

In addition, it has now been clarified that the right of pre-emption terminates when a package sale or sale involving other properties in a wider transaction terminates without 
completion. Completion of the sale that gave rise to the right of pre-emption is a condition precedent to the actual exercise of the right.

The right of first negotiation, unlike pre-emption, arises before the transferor enters into any written agreement for the transfer with a third party, regardless of whether such an agreement is binding. Consequently, the right of first negotiation prohibits a transferor from even entering into a non-binding agreement or memorandum of understanding.

\section{Change in CONTROL REvisions}

Considerable confusion has arisen over the actual effects of the clause on changes in control of a parent company in which the participating interest played a relatively insignificant role in the transaction. As a result, the Revision Committee sought to mitigate this ambiguity by defining a change in control in the $2002 \mathrm{JOA}$, and by employing both vote and value thresholds for determining whether a change in control occurs.

\section{ChOICE OF LAW/DISPUTE RESOLUTION (ARTICl. 18)}

To address circumstances in which the law chosen is less developed than that normally applicable to JOAs, the $2002 \mathrm{JOA}$ includes a choice of law alternative that is made subject to the extent consistent with international law. ${ }^{109}$ Given the arguable and variant meanings of "international law" in the context of the JOA, the second alternative for choice of law should be utilized cautiously. Under the $2002 J O A$, the parties' sole recourse now rests on alternative dispute resolution (ADR) options and a revised arbitration provision. An expert dispute resolution provision was added, but it is reserved to disputes that relate to one of two optional clauses:

(i) preemptive rights relating to a transfer and/or change in control under art. 12. or

(ii) a buy-out in the case of default under art. 8.4.

With regard to the new arbitration clause, the $2002 \mathrm{JOA}$ provides a list of suggested arbitral rules and institutions from which the parties can choose. An optional provision relating to the confidentiality of ADR and arbitration proceedings was also incorporated into the $2002.10 \mathrm{~A}$.

A new waiver of sovereign immunity clause was added as art. 18.4 to ensure that government-owned parties are prevented from claiming sovereign immunity in relation to dispute resolution proceedings or any action brought to enforce any award "that results from an expert determination, mediation, arbitration or any judicial or administrative proceedings" commenced pursuant to the $2002.1 O A .^{110}$ 


\section{Allocation OF HYDROCARBONS (ARTICLE 19)}

In an effort to simplify the provisions governing the allocation of hydrocarbons, the detailed allocation methodology employed by the $1995 \mathrm{JOA}$ was replaced in the $2002 \mathrm{JOA}$. The 2002 JOA sets forth allocation principles and requires that the operator develop, and the Operating Committee adopt, detailed allocation procedures in the future.

\section{ConduCt OF the PARTIES (ARTICLl: 20.1)}

A more generic anti-bribery provision was added that references the principles set forth in the Organization for Economic Co-operation and Development's Anti-Bribery Convention."' An optional provision was also included, obligating the parties to respond in reasonable detail to any notice from another party in connection with the anti-corruption warranty made by the parties under art. 20.1(b).

\section{CONFLICTS OF INTEREST (ARTICLE 20.2(C))}

A party may compete with activities engaged in under the JOA without having an obligation to offer an interest in any other enterprise or venture to another party.

\section{Third Party Beneficiary Clause (ARTicle 20.6)}

In large part to respond to the English Coniract (Right of Third Parties) Act 1999,112 an express provision excluding third parties' rights was added to the $2002 \mathrm{JOA}$. This is to be considered where English law is chosen.

\section{GUIDANCE NOTES}

In addition to the drafting notes offered to change the $2002 J O A$ to reflect a concession/lease contractual regime, and in its effort to render the $2002 \mathrm{JOA}$ a more international friendly agreement, the Revision Committee felt it appropriate to provide civil law guidance notes (the Guidance Notes) to be used in connection with the drafting of JOAs in civil law jurisdictions.

The AIPN also offers its members a black-line version of the $2002 \mathrm{JOA}$ which shows the changes made to the 1995 Form and an in-depth analysis of all revisions, prepared by Philip Weems and Michael Bolton of King \& Spalding LLP.

\footnotetext{
III Jbid. art. 20.1.

112 (U.K.), 1999, c. 31.
} 


\section{APPENDIX A - HABENDUM ClaUSE}

TO HAVE AND ENJOY the same for the term of years (hereinafter called the "said term") from the date hereof and so long thereafter as the leased substances or any of them are produced from the said lands, subject to the sooner termination of the said term as hereinafter provided;

PROVIDED that if operations for the drilling of a well are not commenced on the said lands within one (1) year from the date hereof, this Lease shall terminate and be at an end on the first anniversary date, unless the Lessee shall have paid or tendered to the Lessor on or before said anniversary date the sum of

rental"), which payment shall confer the privilege of deferring the commencement of drilling operations for a period of one (1) year from said anniversary date, and that, in like manner and upon like payments or tenders, the commencement of drilling operations and the termination of this Lease shall be further deferred for like periods successively;

PROVIDED FURTHER that if at any time during the said term and prior to the discovery of production on the said lands, the Lessee shall drill a dry well or wells thereon, or if at any time during such term and after the discovery of production on the said lands such production shall cease and the well or wells from which such production was taken shall be abandoned, then this Lease shall terminate at the next ensuing anniversary date hereof unless operations for the drilling of a further well on the said lands shall have been commenced or unless the Lessee shall pay or tender the delay rental in the manner and within the time hereinbefore provided;

AND FURTHER ALWAYS PROVIDED that if at the end of the said term the leased substances are not being produced from the said lands and the Lessee is then engaged in drilling or working operations thereon, or if at any time after the expiration of the said term production of the leased substances has ceased and the Lessee shall have commenced further drilling or working operations within ninety $(90)$ days after the cessation of said production, then this Lease shall remain in force so long as any drilling or working operations are prosecuted with no cessation of more than ninety $(90)$ consecutive days, and, if such drilling or working operations result in the production of the leased substances or any of them, so long thereafter as the leased substances or any of them are produced from the said lands, provided further that notwithstanding anything hereinbefore contained or implied to the contrary, if drilling or working operations are interrupted or suspended as the result of any cause whatsoever beyond the Lessee's reasonable control or if any well on the said lands or on any spacing unit of which the said lands or any portion thereof from a part, is shut-in, suspended or otherwise not produced for any cause whatsoever which is in accordance with good oil field practice, the time of such interruption or suspension or non-production shall not be counted against the Lessee. 